\title{
The Implementation of Collective Redress - A Comparative Approach
}

\author{
Alexander Stöhr* \\ (Received 13 January 2020; revised 20 March 2020; accepted 20 April 2020)
}

\begin{abstract}
This Article attempts to outline the optimal implementation of collective redress by using a comparative approach. After exploring the weaknesses of individual actions, which should be avoided, this Article presents the main forms of collective redress that exist in the various states. In particular, these forms include: Group action, representative action, and group settlement. The comparison of the various legal orders demonstrates the existence of several important parameters that need to be evaluated in order to design appropriate legislation. As a result, this Article supports alignment with the American class action and proposes specific modifications in order to eliminate several disadvantages of the original model.
\end{abstract}

Keywords: Class action; collective redress; group action; model declaratory lawsuit; representative action

\section{A. Introduction}

In a world of mass production, mass marketing, and economic interdependence, it is not uncommon for many individuals to be harmed in essentially identical ways by mass-produced products or standardized corporate practice. ${ }^{1}$ A current example is the diesel emissions scandal, where automobile manufacturers sold cars that underwent manipulated air pollution tests. ${ }^{2}$ According to the substantive law, buyers of affected cars are able to claim damages. ${ }^{3}$ It is the function of civil procedure to provide an opportunity to determine and enforce subjective rights by means of the courts. Without this opportunity, subjective rights would be worthless, because the state has a monopoly on the use of force. ${ }^{4}$ Civil procedure also serves the public interests by restoring and maintaining legal peace. ${ }^{5}$ However, individual lawsuits are often difficult or not economically reasonable - especially when litigation costs exceed the claim. Furthermore, large companies like Volkswagen usually benefit from being in a superior position, whereas individual

\footnotetext{
${ }^{\star}$ Dr. Alexander Stöhr is a visiting professor at the Johannes Gutenberg University Mainz, Germany. He has previously served as a visiting professor for the Universities at Kassel, Konstanz and Münster.

${ }^{1}$ Janet C. Alexander, An Introduction to Class Action Procedure in the United States, Presented Conference: Debates over Group Litigation in Comparative Perspective, Geneva, July 21-22 (2000), 1.

${ }^{2}$ Damian Carrington, Wide Range of Cars Emit More Pollution in Realistic Driving Tests, Data Shows, The GuARDIAn (Sept. 30, 2015), https://www.theguardian.com/environment/2015/sep/30/wide-range-of-cars-emit-more-pollution-in-real-drivingconditions-tests-show.

${ }^{3}$ Bundesgerichtshof [BGH] [Federal Court of Justice] May 25, 2020, Case No. VI ZR 252/19, para. 24 (May 25, 2020), https://juris.bundesgerichtshof.de/cgi-bin/rechtsprechung/document.py?Gericht=bgh\&Art=en\&nr=106368\&pos=0\&anz=1; Michael Heese, Herstellerhaftung für manipulierte Diesel-Kraftfahrzeuge, NEUE JURISTISCHE WoCHENSCHRIFT, 2019, at 257; Thomas Riehm, Deliktischer Schadensersatz in den “Diesel-Abgas-Fällen,” NeUE JuRISTISCHE WochenSCHRIFT, 1105 (2019).

${ }^{4}$ MÜnCHener Kommentar ZUR Zivilprozessordnung $\$ 8$ (Thomas Rauscher ed., 5th ed. 2016).

${ }^{5}$ See id. at $\$ 9$.
}

(C) The Author(s) 2020. Published by Cambridge University Press on behalf of the German Law Journal. This is an Open Access article, distributed under the terms of the Creative Commons Attribution licence (http://creativecommons.org/licenses/by/4.0/), which permits unrestricted re-use, distribution, and reproduction in any medium, provided the original work is properly cited. 
persons face several access barriers. This shows that individual lawsuits are insufficient in certain cases and because of this, there exists a need for collective redress.

Collective redress is one of the most ubiquitous topics in modern civil law. ${ }^{6}$ The United States has long implemented collective redress in the form of class action lawsuits. For many years after Rule 23 was adopted, the United States was practically the only jurisdiction that permitted collective redress. ${ }^{7}$ However, since 2010, collective redress is on the rise in other jurisdictions as well. ${ }^{8}$ In Europe, the first wave of collective redress emanated from Scandinavia. ${ }^{9}$ Since 2014, the United Kingdom, France, and Belgium followed suit, ${ }^{10}$ followed by countries such as Lithuania, Hungary, and Slovenia. ${ }^{11}$ The German and Dutch regulations will be discussed in more detail later in this Article. Overall, collective redress is implemented unevenly by the member states of the European Union. ${ }^{12}$ At the European level, the European Commission proposed a directive on representative actions in April 2018 as part of the Commission's "New deal for consumers" package, aimed at securing fair and transparent rules for consumers. On June 30, 2020, the Council of the European Union unveiled a directive on representative actions. ${ }^{13}$

These current developments provide an opportunity to take another fundamental look at the topic. The aim of this Article is to develop principles and guidelines for the desirable implementation of collective redress. This is especially relevant with respect to jurisdictions that have either neglected to implement collective redress or done so in a flawed way. While currently only regulations implemented in Germany and in the EU are subject to criticism, other countries may also see reason to scrutinize and-if advisable-modify their regulation. However, none of the existing regulations are exempt from criticism completely, and none should be adopted in their entirety.. It is doubtful whether it is even possible to create a uniformly correct regulation-given the different economic and social backgrounds and legal traditions in the various jurisdictions. Instead of looking for the "philosopher's stone of collective redress," this Article pursues a comparative approach. This Article outlines three main forms of collective redress: Group action, representative action, and group settlement. The Article analyzes various parameters, such as the nature, level, and scope of participation. The central assessment criterion involves analyzing how each parameter serves the purpose of collective redress. Thus, it is essential first to recognize the various aims of collective redress. On the basis of these findings, the best

\footnotetext{
${ }^{6}$ Richard A. Epstein, Class Actions: The Need for a Hard Second Look, CIV. Just. ReP., Mar. 2002, at 1.

${ }^{7}$ Deborah R. Hensler, The Future of Mass Litigation: Global Class Actions and Third-Party Litigation Funding, 79 GEO. WASH. L. ReV. 306, 306 (1991). For developments in the European Union, see Jenny BUCHNER, KolleKTIVER RechtsSCHUtZ FÜr Verbraucher IN Europa 59 (2015).

${ }^{8}$ Zachary D. Clopton, The Global Class Action and Its Alternatives, 19 TheOrETICAL INQUiRIES L. 125, 133-34 (2018) [hereinafter Clopton 1]; concerning collective redress in Canada, see Tanya J. Monestier, Is Canada the New Shangri-La of Global Securities Class Actions?, 32 Nw. J. INT'L L. \& BUS. 305, 364 (2012); concerning collective redress in Israel, see Alon Klement \& Robert Klonoff, Class Actions in the United States and Israel: A Comparative Approach, 19 THEORETICAL INQUiRIES L. 151 (2018).

${ }^{9}$ Group Proceedings Act (Svensk författnings-samling [SFS] 2002:599) (Swed.); Finland (Class Action Act 444/2007), Denmark (2008: Ges. No. 181, 28/2/2007: Sec. 254a-k Administration of Justice Act); Norway (Chap. 35 Act relating to Mediation and Procedure in Civil Disputes); Italy ('Azione di Classe': Art. 140 bis Consumer code, Law Nr. 244 of 2007); Poland (2009: Act on Pursuing Claims in Group Proceedings; amended by the Act on Amending Certain Acts to Facilitate the Seeking of Receivables of 7 April 2017).

${ }^{10}$ Consumer Rights Act 2015, 2015 c. 15, sch. 8 (UK); France (Art. L 423-1 to L.423-32 and R.623-1 to R.623-33 Code de consummation 'Action de groupe', 2014, Titre II, Chap. III); Belgium ('L'action en réparation collective', Livre XVII, Titre 2 Code de droit économique, 2014).

${ }^{11}$ Lithuania (Art.441-1 to 441-17 Code of Civil Procedure 2015, Chapter XXIV); Hungary (Polgári perrendtartás (Civil Procedure Code) MK 2016 No. 190, 7878, Part 8 Chapter XLII of 2016); Slovenia (Law on Collective Actions, Official Journal of the Republic of Slovenia No. 51/2017).

${ }^{12}$ See Rafael Amaro et al., Collective Redress in the Member States of the European Union (Oct. 2018) (study requested by the European Union Committee on Legal Affairs (JURI))

${ }^{13}$ Council Directive 9223/20 of the European Parliament and of the Council on Representative Actions for the Protection of the Collective Interests of Consumers, and Repealing Directive 2009/22/EC, 2020 O.J. [hereinafter Council Directive 9223/20].
} 
component parts of collective redress can be brought together in order to design a better regulation. In the concluding assessment, this Article argues that the American class action model is a suitable model that should be adopted with some specific modifications. As it is unlikely that this solution will be implemented universally, this Article finishes with some suggestions for improving the transposition of the European Union's directive. Alternatives to collective redress, such as means of law enforcement in administrative and criminal law-preferred by some authors $^{14}$ —are not discussed in this Article.

\section{B. Purpose of Collective Redress}

The purpose of collective redress is to provide compensation for the weaknesses of individual redress. ${ }^{15}$ From an economic standpoint, the ultimate goal of this procedure is to generate efficient compliance with the substantive law. ${ }^{16}$ Rational individuals will only use the courts to assert rights if the potential benefits exceed the considerable costs of litigation. Therefore, claims that are too small to cover the cost of litigation will not be pursued. ${ }^{17}$ This is referred to as "rational disinterest." 18 The sum for which such a rational disinterest exists is estimated at 500 to 1,000 euros. ${ }^{19}$ Damage to a large number of persons with a simultaneously low individual amount of damage is referred to as "small claims." ${ }^{20}$ The rational disinterest in filing individual lawsuits becomes problematic when damages accumulate to the level of unlawful profits. In this case, leaving unlawful profits in the hands of the lawbreaker perpetuates the injustice committed and makes it difficult to prevent future infringements. The failure to enforce such claims also provides certain companies with a competitive advantage over law abiding competitors-making the breach of law efficient for the company. ${ }^{21}$ In the case of small claims, there is a supra-individual interest in sanctioning and preventing the breach of law. ${ }^{22}$ The possibility of an efficient breach of law is a market failure in need of correction. ${ }^{23}$ Therefore, collective redress can provide a solution by gathering many individual claims together into a single lawsuit that can support the cost of litigation. ${ }^{24}$ Furthermore, a single judicial decision will prevent parallel litigation, which, for the defendant, can help avoid legal uncertainty and reduce attorneys' fees. ${ }^{25}$

Also problematic are mass tort cases. These cases involve medium-to-large losses-usually occurring in total loss events or in such large numbers that individual actions can be difficult In particular, there is a threat of overloading the judiciary, as courts must adjudicate many similar cases-especially if all damaged parties file suit individually. ${ }^{26}$ An example of this is the

\footnotetext{
${ }^{14}$ Carsten Salger, Das Musterfeststellungsklagegesetz - Stärkung des kollektiven Rechtsschutzes in Deutschland?, jurisPR-BKR 10/2008 Anm. 1.

${ }^{15}$ Eda Şahin, Collective Redress and EU Competition LaW 17 (2018).

${ }^{16}$ Robert G. Bone, Economics of Civil Procedure, in OxFord HandbooK of LAW AND Economics (Francesco Parisi ed., 2017).

${ }^{17}$ Alexander, supra note 1 , at 1 .

${ }^{18}$ Caroline Meller-Hannich, Sammelklagen, Gruppenklagen, Verbandsklagen - Bedarf es neuer Instrumente des kollektiven Rechtsschutzes im Zivilprozess?, Ergebnisse der Legal Research Group zum 72, DeUTSCHEN JURISTENTAG, Sep. 25, 2018, at A3, 24; Caroline Geiger, Kollektiver RechtsschutZ - Die neue Musterfeststellungsklage im Zivilprozess 22 (2015); Michael Heese, Die Musterfeststellungsklage und der Dieselskandal, JURISTENZEITUNG, 429, 431 (2019).

${ }^{19}$ Roland ReChTSREPORT 36 (2014); Opinion Research Group, Spezial-Eurobarometer, EuropeAn COMMISSION 13 (2004).

${ }^{20}$ Meller-Hannich, supra note 18 , at 25.

${ }^{21}$ Deutscher BundesRat: Drucksachen [BR] 19/2507 (Ger.); Raphael Koch, Die Musterfeststellungsklage, Monatsschrift FÜr Deutsches Recht 1409, 1411 (2018).

${ }^{22}$ Meller-Hannich, supra note 18 , at 25.

${ }^{23}$ Christian Alexander, Marktsteuerung durch Abschöpfungsansprüche, JURISTENZEITUNG 890, 893-94 (2006).

${ }^{24}$ Alexander, supra note 1 , at 10.

${ }^{25}$ Dagmar Kranz, Der Diskussionsentwurf zur Muster-Feststellungsklage - ein stumpfes Schwert?, NEUE ZEITSCHRIFT FÜR GESELlSCHAFTSRECHT 1099, 1100 (2017); Koch, supra note 21, at 1411.

${ }^{26}$ Geiger, supra note 18, at 20; Matthis Peter, Zivilprozessuale GrupPenvergleichsverfahren: EINVERnEHMLICHE Streitbeilegung IM KOLLeKTIVEN Rechtsschutz 1 (2018); Heese, supra note 18, at 431. For criticism of this argument,
} 
aforementioned diesel scandal. ${ }^{27}$ In such cases, because the economic existence of the defendant may be at stake, defendants usually defend themselves using all available resources-making procedural equality of arms rare. ${ }^{28}$ The highly complex litigation in mass tort cases further reduces the willingness and ability of individual plaintiffs to bear its costs. ${ }^{29}$ Collective redress counters this effect by lowering the cost of organization. ${ }^{30}$ Furthermore, the concentration of the lawsuits secures greater uniformity of judicial decisions. ${ }^{31}$

This shows that collective redress also serves the purpose of substantive law. If there are no means by which legal rights can be enforced, the law might be considered a failure, for it can be violated with impunity. ${ }^{32}$ Failure occurs when there are incentives to refrain from asserting a claim. This is the case when small claims and mass torts are not enforced for economic reasons. Therefore, by making it possible to litigate small claims and mass torts, collective redress serves the goals of compensation and deterrence. ${ }^{33}$ The implementation of collective redress can even be required by the constitution. ${ }^{34}$ If an individual procedure is subject to such high legal or factual hurdles that there are incentives not to sue, the constitutionally guaranteed access to justice is impaired. ${ }^{35}$ As such, there should be proper alternatives, or access must be affirmatively facilitated.

It is important to bear in mind, however, that economic efficiency is not the only metric for evaluating procedure. One might instead focus on the principles of justice and equity. ${ }^{36}$ In this respect, collective redress can be a way of leveling the playing field for economically less powerful individuals. In civil litigation, large businesses have significantly larger chances of success because of their special knowledge and process experience. ${ }^{37}$ Due to their size, large businesses can bear the risk of individual lawsuits better than an individual person. They often have established connections to courts and lawyers. The body of evidence also tends to favor large businesses because they routinely file documentation with the courts and have employees who are willing to come forward as witnesses.

Individual persons, in contrast, are at a disadvantage in several respects. As a baseline, it is more difficult for an individual to obtain access to courts. Moreover, sociological findings have shown that there are several other access barriers. ${ }^{38}$ In particular, there may be personal deficits-such as a lack of language skills or legal knowledge, or even a fear of superior opponents. Not everybody is able to get through a lengthy procedure and deal with conflict that may reduce the joys of life. Economical barriers consist of the high level and incalculability of costs. Empirical results show that litigation costs have a deterrent effect if the outcome of procedure is uncertain. ${ }^{39}$ A typical consumer does not have the resources of a typical business. Furthermore, there may be social barriers - such as the reservations and prejudices held by the courts and lawyers-because of

see Alexander Bruns, Instrumentalisierung des Zivilprozesses im Kollektivinteresse durch Gruppenklagen?, NEUE JURISTISCHE WOCHENSCHRIFT 2753, 2756 (2018).

${ }^{27}$ Meller-Hannich, supra note 18 , at 26.

${ }^{28} I d$.

${ }^{29}$ Epstein, supra note 6, at 1 .

${ }^{30}$ Thomas S. Ulen, The Economics of Class Action Litigation, in The LAW AND ECONOMICs OF Class Actions IN EUROPE 79 (2012)

${ }^{31}$ Bernd Scholl, Die Musterfeststellungsklage nach $\$ \$ 606 \mathrm{ff} . \mathrm{ZPO}$, Zeitschrift für die gesamte Privatrechtswissenschaft 317, 327 (2019).

${ }^{32}$ Alexander, supra note 1 , at 1 .

${ }^{33}$ Judith Resnik, Money Matters: Judicial Market Interventions Creating Subsidies and Awarding Fees and Costs in Individual and Aggregate Litigation, 148 U. PENN. L. REv. 2119 (2000); Clopton 1, supra note 8, at 126.

${ }^{34}$ Sonja Lange, Das Begrenzte Gruppenverfahren 98 (2011); Meller-Hannich, supra note 18, at 38.

${ }^{35}$ Meller-Hannich, supra note 18 , at 38 .

${ }^{36}$ Bone, supra note 16, at 144; Ronald A. DWOrkin, A Matter of Principle 72 (1985).

${ }^{37}$ Manfred Rehbinder, RechtsSOZiologie 157 (8th ed. 2014).

${ }^{38}$ JoAchim Goebel, ZivilprozeßrechtSdogmatik Und VerfahrensSOZiologie 80 (1994); Thomas Raiser, RECHTSSOZIOLOGIE 304 (2007); ReHBINDER, supra note 37, at 146; ŞAHIN, supra note 15, at 28.

${ }^{39}$ GoEBel, supra note 38 , at 317 . 
an individual's social background. Finally, there may exist legal barriers such as: Excessive complexity of rules, contingencies regarding the outcome of the trial, an inconvenient jurisdiction, or limited access to legal counsel. In sum, an individual, especially a poor person, is at a great disadvantage in court against a well-financed, corporate opponent who can afford expensive legal advice.

Those disadvantages can be reduced when claims are brought together in collective redress because the aggregate amount may be large enough to make it possible to engage the services of equally skilled counsel. ${ }^{40}$ In view of this, a parallel can be drawn to the protection of employees via collective bargaining. The main goal of labor law has always been to compensate for the inequality of bargaining power: "[T]he relationship between an employer and an isolated employee is typically a relationship between a bearer of power and one who is not a bearer of power." 41 Accordingly, only through employee aggregation and protective legislation can the exploitation of employees be prevented. ${ }^{42}$ Trade unions may use their collective power to improve wages and working conditions. ${ }^{43}$

\section{Main Forms of Collective Redress \\ 1. Group Action}

"Group actions" are a form of collective redress in which the damaged parties themselves, represented by a representative plaintiff, can take part. The archetype group action is the American-style class action. In the United States, the general rule for class actions is codified in Rule 23 of the Federal Rules of Civil Procedure (FRCP). According to Rule 23(a), the prerequisites to any class action are: (1) That the class is "so numerous that joinder of all members is impracticable"; (2) there are "questions of law or fact common to the class"; (3) "the claims or defenses of the representative parties are typical of the claims or defenses of the class"; and (4) the representative parties will "fairly and adequately protect the interests of the class." 44 The next requirement is that the action must fit into one of three categories in Rule 23(b). Most class actions fall under the third category, meaning that the questions common to the class must predominate over any questions that affect only individual class members, and that class treatment must be "superior to other available methods for the fair and efficient adjudication of the controversy." 45

The class representative is self-nominated-all one has to do to start a class action is file a complaint stating that the suit is being brought as a class action, and make allegations sufficient to satisfy the requirements of Rule 23(a) and Rule 23(b). ${ }^{46}$ According to Rule 23(c), the court has to determine "as soon as practicable" after the case is filed whether it may be maintained as a class action. ${ }^{47}$ If so, the class is "certified." Of particular importance is the opt-out regulation: Persons falling within the parameters of the class are automatically included in the class and any court orders or settlements will apply to all members of the class, unless the putative member opts-out. According to Rule 23(b)(2), notice must be given to the members of the class that,

\footnotetext{
${ }^{40}$ Alexander, supra note 1, at 1 . See also Joseph Stiglitz, People, Power ANd Profits 78 (2020).

${ }^{41}$ Paul Davies \& Mark Freedland, Kahn-Freund's Labour and the Law 18 (3d ed. 1983); Slaight Communications v. Davidson, [1989] 1 S.C.R. 1038, 1051 (Can.).

${ }^{42}$ Manfred Weiss, The Idea of Labour Law 43 (Guy Davidov \& Brian Langille eds., 2011).

${ }^{43}$ Bundesverfassungsgericht [BVerfG] [Federal Constitutional Court], Case No. 1 BvR 779/85, June 26, 1991, https:// openjur.de/u/177422.html; GuY Davidov, A Purposive Approach to Labour Law 229 (2016); Ruth Dukes, The Labour Constitution: The Enduring Idea of Labour Law 72 (2014); Wolfgang Däubler, Tarifvertragsgesetz 95 (4th ed. 2016).

${ }^{44}$ FED. R. CIV. P. 23(a).

${ }^{45} I d$. at $23(\mathrm{~b})$.

${ }^{46}$ Alexander, supra note 1 , at 6 .

${ }^{47}$ FeD. R. CIV. P. 23(c).
} 
among others, a class action on their behalf has been certified and that the court will exclude from the class any member who requests exclusion, or "opts out," of the class. ${ }^{48}$

No European country has adopted the American-style class action verbatim. However, the English counterpart is relatively close to the American model. In 2015, the United Kingdom introduced the Consumer Rights Act, which complements existing regulations. ${ }^{49}$ The rules governing disclosures are one way that these regulations are comparable to rules in the U.S. The English courts are required to limit disclosure to what is strictly necessary to deal with the case justly. Similarly, Rule 26(b)(1) stipulates that "parties may obtain discovery regarding any nonprivileged matter that is relevant to any party's claim or defense and proportional to the needs of the case ... ."50 On other issues, however, the regulations differ. ${ }^{51}$ For instance, the English regulation is restricted to actual damages and does not provide for punitive damages. According to Parts 26 and 36 of the English Civil Procedure Rules, a permission of the court for settlements is usually not required, whereas under Rule 23(b)(3) of the American FRCP, any settlement requires court approval. In the United Kingdom, the prevailing party will recover their litigation costs — including attorneys' fees_-whereas in the United States, the general rule is that each party will bear its own costs of litigation.

\section{Representative Action}

\section{Model Declaratory Lawsuit}

A unique form of representative action exists in Germany. The model declaratory lawsuit (Musterfeststellungsklage) was established on November 1, 2018, and is implemented in Sections 606-14 of the German Code of Civil Procedure. The law was passed hastily, because it had to be in effect by the second half of 2018 in order to protect purchasers of Volkswagen vehicles from the tolling period which would have ended in 2018. ${ }^{52}$ Accordingly, the law is critically dubbed "Lex Volkswagen." 53

A model declaratory lawsuit will allow consumer protection associations, on behalf of large numbers of consumers, to receive a binding declaratory judgment from the court on the consumers' legal position-or at least substantial legal prerequisites for them to assert claims against companies. The model declaratory lawsuit is not aimed at obtaining an enforceable title. Instead, such lawsuits aim to clarify factual and legal preliminary questions that are relevant in all individual cases. The judgement has no further legal consequences, as these judgments neither direct compensation nor prohibit illegal business practices.. While a court can determine the lawfulness of a particular business practice, ${ }^{54}$ in order to obtain an enforceable title, consumers have to proceed with an individual lawsuit, unless they reach an out-of-court solution for their dispute. The decisions taken in the model declaratory lawsuit are binding, but only on the legal relations between the consumers and the defendant company. In contrast to the American-style class action, only the applicant consumer protection associations are parties to the trial, not the consumers themselves. The model declaratory lawsuit is based on the opt-in principle.

\footnotetext{
${ }^{48} I d$. at $23(\mathrm{~b})(2)$.

${ }^{49}$ Any reference to the UK is to the legal jurisdiction of England and Wales.

${ }^{50}$ Fed. R. Civ. P. 26(b)(1).

${ }^{51}$ See David Niven \& Kim Stephenson, Collective Redress: A Comparison between the UK and the US, PENNINGTONS MANCHES COOPER (Sep. 3, 2018), https://www.penningtonslaw.com/news-publications/latest-news/2018/transatlanticlitigation-collective-redress-a-comparison-between-the-uk-and-the-us.

${ }^{52}$ Astrid Stadler, Kollektiver Rechtsschutz - Chancen und Risiken, in ZEITSCHRIFT FÜR DAS GESAMTE HANDELSRECHT UND WIRTSCHAFTSRECHT 623, 626 (2018) [hereinafter Stadler 1].

${ }^{53} I d$. at 626; see also Heese, supra note 18 , at 429.

${ }^{54}$ Karoline Borwiek \& Remo Klinger, Consumer Protection Rights in Europe: A Comparison of Collective Redress Systems in Six Selected EU Countries in the Case of False Fuel Consumption Figures, GET REAL (Jan. 2019), https://www.get-real.org/wpcontent/uploads/2019/05/GetReal_Verbraucher-Studie_210519_EN_final.pdf.
} 
Consumers who file their claims with the court register have no influence on the procedure, but are subject to the binding effect of the judgment or settlement. ${ }^{55}$ On the one hand, consumers benefit from the advantage of a cost-free preliminary clarification of their possible claims. On the other hand, they bear the risk of legal disadvantages as a result of their passive role. ${ }^{56}$

On February 28, 2020, an out-of-court settlement was reached between the German consumer group, Verbraucherzentrale Bundesverband, and Volkswagen to compensate buyers affected by the diesel emissions scandal. This settlement ended the model declaratory lawsuit. Buyers who did not accept the terms of the settlement had to continue pursuing their interests via individual lawsuits. ${ }^{57}$ It remains to be seen whether the model declaratory lawsuit will be of any importance after this legal dispute-regarded as the "Raison d'Être"-has been settled.

\section{Directive on Representative Actions}

In 2013, the European Commission issued a non-binding recommendation for a European Collective Action model. After this model was passed over by all member states, the Commission devised a new approach. ${ }^{58}$ On April 11, 2018, the Commission published a proposal for a "Directive of the European Parliament and of the Council on representative actions for the protections of the collective interests of consumers, and repealing Directive 2009/22/EC." 59 The Parliament's plenary committee adopted the proposal for a directive on March 26, 2019. Because the directive merely aims to achieve a minimum harmonization, ${ }^{60}$ the member states may retain already existing, more far-reaching instruments of collective legal protection. On November 28, 2019, the Council of the European Union reached an agreement on a draft directive, which included minor modifications superseding the original proposal. ${ }^{61}$ The Council of the European Union published the agreed text of the directive on representative actions on June 30,2020 - much sooner than expected. ${ }^{62}$

The directive shall enable qualified entities to bring collective actions to prevent and prohibit trading practices that breach the law. Like the German model declaratory lawsuit, the Commission's approach has been significantly influenced by the diesel scandal and Volkswagen's initial refusal to compensate European consumers in violation of its agreement with United States authorities. ${ }^{63}$ According to the directive, qualified entities such as consumer protection associations should be entitled to sue, but this does not include other companies or law firms. ${ }^{64}$ Such qualified entities may seek injunction and redress measures, which have been slightly modified in comparison with the original proposal. ${ }^{65}$ According to Article 5a (1), the

\footnotetext{
${ }^{55}$ Peter Röthemeyer, Das rechtliche Gehör im Musterfeststellungsverfahren, in MONATSSCHRIFT FÜR DEUTSCHES RECHT 6 (2019).

${ }^{56} I d$.

${ }^{57}$ James Attwood, Volkswagen Reaches $£ 698$ million Dieselgate Settlement in Germany, AuTOCAR (Feb. 28, 2020), £https:// www.autocar.co.uk/car-news/industry/volkswagen-reaches-£698-million-dieselgate-settlement-germany.

${ }^{58}$ Christopher Hodges, Collective Redress: The Need for New Technologies, J. COnsumer PoL'y 59, 70 (2019); Tanja Domej, Die geplante EU-Verbandsklagerichtlinie, ZEITSCHRIFT FÜR EUROPÄISCHES PRIVATRECHT 446 (2019).

${ }^{59}$ Proposal for a Directive of the European Parliament and of the Council on Representative Actions for the Protection of the Collective Interests of Consumers, and Repealing Directive 2009/22/EC, COM (2018) 184 final (Apr. 11, 2018).

${ }^{60}$ European Parliament legislative resolution of 26 March 2019 on the proposal for a directive of the European Parliament and of the Council on representative actions for the protection of the collective interests of consumers, and repealing Directive 2009/ 22/EC (COM(2018)0184 - C8-0149/2018 - 2018/0089(COD)), Recital 24.

${ }^{61}$ Council Directive 14600/19, Proposal for a Directive of the European Parliament and of the Council on Representative Actions for the Protection of the Collective Interests of Consumers, and Repealing Directive 2009/22/EC, 2018, O.J [hereinafter Council Directive 14600/19].

${ }^{62}$ Council Directive 9223/20, supra note 13 .

${ }^{63}$ Hodges, supra note 58 , at 71 .

${ }^{64}$ Proposal for a Directive of the European Parliament and of the Council on Representative Actions for the Protection of the Collective Interests of Consumers, and Repealing Directive 2009/22/EC, at 3, COM (2018) 184 final (Apr. 11, 2018).

${ }^{65}$ Council Directive 14600/19, supra note 61, at arts. 5, 6 .
} 
injunction measures are: (a) A provisional measure to cease or, where appropriate, to prohibit a practice deemed to constitute an infringement; (b) a definitive measure to cease or, where appropriate, to prohibit a practice that constitutes an infringement. ${ }^{66}$ Article 5a (2) states that the qualified entity shall not have to prove the actual loss or damage on the part of individual consumers affected by an infringement nor the intention or negligence on the part of the trader. ${ }^{67}$ According to Article 5b (1), a redress measure shall oblige the trader to provide consumers concerned with remedies such as compensation, repair, replacement, price reduction, contract termination, or reimbursement of the price paid, as appropriate and as available under Union or national law. ${ }^{6}$ The remedies provided by redress measures within a representative action shall be to any additional rights to redress that the consumers concerned may have under Union or national law, Article 5b (10). ${ }^{69}$

According to Recital $10,{ }^{70}$ the entitlement to litigate presupposes that the qualified entities operate independently, transparently, and without conflict of interest. Financial agreements with law firms, for example, are therefore excluded. The scope of application is mainly limited to the field of consumer protection. In particular, the scope of the directive would be defined by whether infringement of the acts listed in Annex I occurred. This effect should already exist with two consumers. ${ }^{71}$ In contrast to the German model declaratory lawsuit, the subject of the representative action is not merely a declaratory judgement on a legal question. Rather, the qualified entity should also be able to collectively enforce injunctive relief and remedy claims from the tortfeasor.

The European Parliament also wants all of its member states to prevent parallel collective actions from taking place in various Members State jurisdictions. However, the European Parliament does not describe exactly how this can be achieved. The European Parliament demands only a few safety standards. Namely, that the losing party should have to pay for legal costs, which should limit abusive lawsuits, and that contingency fees are excluded. This is in line with the tradition of Member States, where contingent fees were strictly forbidden. ${ }^{72}$ Though, it is unclear whether the Parliament's safety standards are permissible under German constitutional law. In addition, Member States should not be allowed to award punitive damages, as expressed in Recitals 4 and 15a. Nevertheless, on March 22, 2019, the European Union Council of Ministers, the European Parliament, and the European Commission agreed within the framework of the socalled New Deal for Consumers that-should infringements of the Unfair Commercial Practices Directive 2005/29/EC, the Consumer Rights Directive 2011/83/EU, the Unfair Terms Directive 93/13/EEC, and the Price Indication Directive 98/6/EC occur-not only can consumers claim damages, but authorities can also impose fines on top of those claimed damages. In fact, a multi-tier punishment is proposed here. In addition, in Germany, there is still the possibility of receiving a warning letter from competitors.

\section{Group Settlement}

Another approach is the group settlement, as followed in the Netherlands. The "Wet Collectieve Afwikkeling Massaschade" (WCAM) was established on July 27, 2005 and was implemented in Articles 907-910 of Book 7 of the Dutch Civil Code and Article 1013 of the Dutch Code of Civil

\footnotetext{
${ }^{66} I d$. at art. 5(a)(1).

${ }^{67} I d$. at art. 5(a)(2).

${ }^{68} \mathrm{Id}$. at art. 5(b)(1).

${ }^{69} \mathrm{Id}$. at art. 5(b)(10).

${ }^{70} \mathrm{Id}$. at rec. 25.

${ }^{71}$ Geoffroy Didier, Committee on Legal Affairs, Proposal for a Directive of the European Parliament and of the Council on Representative Actions for the Protection of the Collective Interests of Consumers, and Repealing Directive 2009/22/EC, at request no. 6 concerning recital 6a (Dec. 7, 2018).

${ }^{72}$ See Winand Emons, Legal Fees and Lawyers' Compensation, in OxFORD HANDBOoK OF LAW AND ECONOMICS 247 (Francesco Parisi ed., 2019).
} 
Procedure. The WCAM provides for collective redress on the basis of a settlement agreement between one or more representative organizations and one or more allegedly liable parties for the benefit of a group of affected persons to whom damage was allegedly caused. ${ }^{73}$ A settlement agreement is reached before and without the intervention of a court. In contrast to the group action and representative action, there are no plaintiffs or defendants under the group settlement approach-merely applicants who jointly request the binding effect of a settlement for a group of affected persons. ${ }^{74}$ Once a collective settlement is reached, the parties may jointly request the Amsterdam Court of Appeal - the only competent court to oversee a WCAM process- to declare the settlement binding. According to Article 907(3), the Court declares the settlement binding after evaluating two main aspects of the agreement: (1) The representation of the foundation(s) and association(s), as the Court will examine whether the representative foundation or association sufficiently represents the interests of the persons pursuant to its articles of association; and (2) the reasonableness of the settlement, as the Court will reject the request for binding effect if the amount of compensation awarded in the settlement agreement is not reasonable. ${ }^{75}$ If the Court grants the request, the agreement binds all persons covered by its terms and represented by the representative organization, except for any person who has expressly elected to opt out within a specific period. ${ }^{76}$ An appeal to the Supreme Court is only possible on joint petition by all applicants, and only if the Court has rejected the request to declare the agreement binding. One of the earliest settlements to use the WCAM process involved approximately 11,000 insurance policy holders from across Europe, the United States, and Thailand. ${ }^{77}$

On March 19, 2019, the Dutch Senate approved the legislation introducing collective damages actions, "Wet Afwikkeling Massaschade in Collectieve Actie" (WAMCA). The legislation introduced an option to claim monetary damages in a group action. The law was entered into force on January $1,2020 .^{78}$

\section{Parameters for the Implementation of Collective Redress}

None of the presented regulations are exempt from criticism. It is therefore time to make some fundamental considerations regarding the desirable implementation of collective redress. It must be borne in mind that a regulation has to compensate for the above-mentioned disadvantages of individual redress in an economically feasible manner. The regulation has to ensure that damaged parties can protect their rights and that the interests of the tortfeasor and the economy as a whole are adequately taken into account. Therefore, the regulation must not only serve both individual and collective interests, it must also strike a reasonable balance between the injured party and the company. A comparison of the various forms of collective redress indicates the existence of several essential parameters. ${ }^{79}$

\section{Entitlement to Litigate: Group Action vs. Representative Action}

First, there is the entitlement to litigate, which determines whether parties themselvesrepresented by a representative plaintiff, or merely associations-can file and be parties to the lawsuit. A limitation to associations is found, per definition, in representative action - which exists, for example, in the form of the German model declaratory lawsuit and EU directive, as

\footnotetext{
${ }^{73}$ Helene van Lith, The Dutch Collective Settlements Act and Private International Law 16 (2010).

${ }^{74} \mathrm{Id}$. at 18 .

${ }^{75}$ Art. 907(3) BW.

${ }^{76}$ Hodges, supra note 58 , at 76 .

${ }^{77}$ Clopton 1, supra note 8 , at 134 .

${ }^{78}$ See Stb. 2019, 130 Collectieve Afwikkeling Massaschade, NEDERLANDS JURISTENBLAND (Apr. 9, 2019), https://www.njb.nl/ wetgeving/staatsbladen/collectieve-afwikkeling-massaschade/.

${ }^{79}$ Amaro et al., supra note 12 , at 69.
} 
well as in Belgium, the Netherlands, and Spain. ${ }^{80}$ Private parties are involved in group actions, which exists in the United States, as well as in Bulgaria, Denmark, England and Wales, Finland, Lithuania, Poland, and Sweden. Combination models exist in France, Hungary, and Italy, where there is representative action and individual consumers may join at a later stage. Allowing injured parties to be parties in a trial means that the trial is usually conducted by private lawyers. Indeed, in jurisdictions which permit participation of the damaged party, like in the United States, it becomes profitable for lawyers to specialize in class action litigation. Accordingly, a market for private enforcement of the law developed. ${ }^{81}$

The legal role of class action lawyers is a matter of perception. Critics of the American model like to call them "bounty hunters." 82 By contrast, courts in favor of this model view them as "private Attorney Generals," privately vindicating rights through lawsuits that public officials do not have the resources to pursue. ${ }^{83}$ Unsurprisingly, capitalistic guardianship is not identical to altruistic or governmental guardianship, because it is driven predominantly by concerns of profit. ${ }^{84}$ This profit motive works well when the capitalistic interests of the guardian are inherently intertwined with the interests of its "wards," but that is not always the case. ${ }^{85}$ For better or worse, private enforcers are motivated by private interests. On the contrary, there will often be potential conflicts of interest between lawyers and their clients inherent in the class action procedure. ${ }^{86}$ The main interest of the damaged parties is to maximize net recovery-which is calculated by taking the final settlement or judgment, less litigation expenses and attorneys' fees, and discounted for the time that must elapse before the money is distributed to the class. The class counsel's interest is in maximizing their effective hourly fee-which is the fee that is eventually obtained, divided by the number of hours worked on the case, then also appropriately discounted for the time elapsed before the fee is collected. The plaintiffs' lawyer has strong incentives to settle the case rather than go to a potentially promising trial, because a trial adds a substantial amount of work to the case. ${ }^{87}$ There is empirical evidence that class action settlements often do not appear to be made in the class's best interests. ${ }^{88}$ The opposite can also be the case, where class attorneys fight zealously to prevent their clients from being denied the protections of notice and opt-out. ${ }^{89}$ This conflict of interest is exacerbated by the fact that clients are anonymous and absent from court proceedings. As absent clients are often faceless and nameless to their class attorneys, the likelihood of abuse, which is normally low because of the bond stemming from the attorney-client relationship, increases as a result of the clients' anonymity. ${ }^{90}$ It is not surprising that this conflict of interest is mentioned as a reason for

\footnotetext{
${ }^{80}$ Daniel M. Klocke, Rechtsschutz in Kollektiven Strukturen: Die Verbandsklage im Verbraucher-Und ARBeitsRecht (2016).

${ }^{81}$ Alexander, supra note 1 , at 2.

${ }^{82}$ John C. Coffee, Jr., Rescuing the Private Attorney General: Why the Model of the Lawyer As Bounty Hunter Is Not Working, 42 MD. L. REV. 215, 218 (1983).

${ }^{83}$ Assoc. Indus. of N.Y.C, Inc. v. Ickes, 134 F.2d 694, 704 (2d Cir. 1943); Stewart v. Gen. Motors Corp., 756 F.2d 1285, 1294 (7th Cir. 1985); W.B. Rubenstein, On What a 'Private Attorney General' Is—and Why It Matters, 57 VAND. L. REV. 2129,2136 (2004).

${ }^{84}$ Martin H. Redish, Rethinking the Theory of the Class Action: The Risks and Rewards of Capitalistic Socialism in the Litigation Process, 64 EMORY L. J. 451, 464 (2014) [hereinafter Redish 1].

${ }^{85}$ Martin H. Redish, Wholesale Justice: Constitutional Democracy and the Problem of the Class Action LAwsuit 30 (2009) [hereinafter Redish 2].

${ }^{86}$ Zachary D. Clopton, Diagonal Public Enforcement, 70 StAN. L. Rev. 1077 (2018); John C. Coffee Jr., Class Action Accountability: Reconciling Exit, Voice, and Loyalty in Representative Litigation, 100 Colum. L. REV. 370 (2000); Bruce Hay \& David Rosenberg, Sweetheart and Blackmail Settlements in Class Actions: Reality and Remedy, 75 Notre DAME L. REV. 1377 (2000); Redish 1, supra note 84, at 451.

${ }^{87}$ Alexander, supra note 1 , at 17.

${ }^{88} \mathrm{Id}$. at 17.

${ }^{89}$ Wal-Mart Stores, Inc. v. Dukes, 564 U.S. 338 (2011).

${ }^{90}$ Redish 2, supra note 85 , at 62 .
} 
permitting only registered associations to conduct the trial. Such associations are usually co-financed by the state and therefore do not strive for their own profits. ${ }^{91}$

However, this consideration is not decisive. Such considerations are a typical example of a principal-agent conflict, which occurs when one person is able to make decisions on behalf of another. In modern economic life, which relies on the division of labor, principal-agent conflicts cannot be completely prevented. Other examples are external managers, stockbrokers, and even real-estate agents. ${ }^{92}$ The same applies to lawyers. Lawyers are only human, and humans respond to incentives. Instead of excluding damaged parties and their lawyers from the trial, the regulation should instead seek to limit the impact of such conflicts of interest by establishing reasonable precautions. In the United States, the certification requirements of Rule 23(a) require that named parties and their attorneys adequately represent the class, and that every settlement of a certified class proceeding must be approved by the court. Even if these mechanisms are ineffective in wholly preventing such abuses, as Martin $\mathrm{H}$. Redish argues, ${ }^{93}$ a possible solution might be to find some mechanism to mimic the presence of a client, so that lawyers continue to look out for the class's interest, even if clients remain largely anonymous throughout the process. ${ }^{94}$

Apart from the conflict of interests, there are substantial arguments in favor of the group action model. First, it is difficult to establish liability on the part of the association for defective litigation. ${ }^{95}$ It is problematic that court decisions are binding, despite the lack of one party's participation. ${ }^{96}$ Second, associations possess substantial financial endowments, and can afford to hire private plaintiff lawyers. Private plaintiff lawyers are often more professional and competent than public institutions, but above all, they have more flexibility to use personal and financial resources. ${ }^{97}$ Authorities that are less financially able cannot intervene across the board, and are directly exposed to political influence. ${ }^{98}$ The European Union approach, with its combination of association litigation powers and significant legal and factual restrictions on litigation funding, is considered to be the worst of all solutions - as not-for-profit institutions can hardly manage the cost of collective litigation. ${ }^{99}$ The requirement of state support, according to Article 15 of the directive, which is supposed to solve the problem, ${ }^{100}$ leads to associations' dependence on the state-fundamentally contradicting the idea of private enforcement. ${ }^{101}$ The German approach is also widely criticized for excluding the damaged parties and their lawyers. ${ }^{102}$ Therefore, associations should only be allowed to litigate if damaged parties are able to file suit themselves. Claimants should have a say in who they appoint as their representative. ${ }^{103}$ There is no need to fear a large number of frivolous lawsuits ${ }^{104}$ as long as the threshold for filing a lawsuit is highparticularly because of the obligation to bear costs in the event of an unfavorable outcome. ${ }^{105}$

\footnotetext{
${ }^{91}$ Clopton 1 , supra note 8 , at 148 .

${ }^{92}$ SteVen D. LEVitT \& Stephen J. Dubner, Freakonomics 7 (2005).

${ }^{93}$ Redish 1 , supra note 84 , at 466.

${ }^{94}$ Alexander, supra note 1 , at 19.

${ }^{95} \mathrm{Koch}$, supra note 21 , at 1415 .

${ }^{96}$ Burkhard Schneider, Die zivilprozessuale Musterfeststellungsklage, in BETRIEBS-BERATER 1986, 1995 (2018).

${ }^{97}$ John C. Coffee, JR., ENTrepreneurial Litigation 222 (2015).

${ }^{98}$ Stadler 1 , supra note 52 , at 637.

${ }^{99}$ Axel Halfmeier \& Peter Rott, Verbandsklage mit Zähnen? Zum Vorschlag einer Richtlinie Über Verbandsklagen ZUM SCHUTZ DER KollekTivinteressen Der VerbraUCher 243, 247 (2018); Matthias Kilian, Musterfeststellungsklage - Meinungsbild der Anwaltschaft, in ZEITSCHRIFT FÜR RECHTSPOLITIK 72, 73 (2018).

${ }^{100}$ Domej, supra note 58 , at 463.

${ }^{101}$ Stadler 1, supra note 52, at 650.

${ }^{102}$ Stadler, Kollektiver Rechtsschutz quo vadis?, in JURISTENZEITUNG 793, 801 (2018) [hereinafter Stadler 2]; Koch, supra note 21 , at 1414 .

${ }^{103}$ Halfmeier, Popularklagen im Privatrecht 383 (2006); Meller-Hannich, supra note 18, at 77.

${ }^{104}$ See Scholl, supra note 31 , at 331.

${ }^{105}$ Meller-Hannich, supra note 18 , at 77.
} 


\section{Nature of Participation: Opt-Out Principle vs. Opt-In Principle}

With regard to the nature of participation, one can distinguish between the opt-in principle and the opt-out principle. The opt-in principle means that damaged parties must actively participate in the process-and court decisions and settlements are not applicable to those who have not opted in. ${ }^{106}$ Therefore, claimants who take no action will not be a part of the process, and will not be precluded from bringing a separate lawsuit. ${ }^{107}$ Although the opt-in principle is often connected with representative actions, there is actually no correlation. It is implemented, for example, in the German model declaratory lawsuit, as well as in France, Hungary, Italy, Lithuania, Poland, and Sweden. The opt-out principle means that the outcome of the process affects all damaged parties in the case at hand, even if they did not actively choose to take part in the process. ${ }^{108}$ An example is the American class action. In Europe, the opt-out principle is implemented by the United Kingdom and the Netherlands. Hybrid systems of either opt-in or opt-out, depending on the type of action or the specifics of the case, can be found in Belgium, Bulgaria, Denmark, and competition cases in the United Kingdom. At the European level, after the Commission's 2013 recommendation aimed at the opt-in principle, the European Union Directive leaves it up to the Member States to choose between the opt-in principle, the opt-out principle, or a combination of both. ${ }^{109}$

On the one hand, an advantage of the opt-in principle is that it addresses the concerns of those affected, because claimants must express their desire to be included in the action during a specified timeframe. ${ }^{110}$ On the other hand, the main disadvantage of the opt-in principle is that it does not sufficiently overcome the rational disinterest in small claims cases. ${ }^{111}$ Conversely, the opt-out principle allows the damaged parties to exert stronger pressure on the tortfeasor. ${ }^{112}$ Accordingly, the opt-out principle furthers the objective of collective redress, and is preferable for this reason. However, Redish argues that the opt-out principle violates individual rights by erasing an individual's cause of action in favor of the collective. ${ }^{113}$ Redish invokes litigant autonomy as a central value of democracy, and explains that, as a due process matter, rights would belong to individuals - and should not be taken away by the operation of a procedural rule, unless individuals willingly choose to participate in that process. ${ }^{114}$ Litigants have a right to freedom of association or, rather, freedom to be free from association with a class. ${ }^{115}$ For this reason, opt-out class actions violate due process. Furthermore, the binding of parties-including those that have not consciously joined the trial— to court decisions may limit the right to a fair hearing. Therefore, according to Redish, collective redress should only be opt-in. ${ }^{116}$

While these concerns should not be dismissed easily, they do not fundamentally question the opt-out principle. Wiewiórowska-Domagalska shares these constitutional concerns with regard to the Polish law, but acknowledges that the opt-out principle could be the ideal solution in small cases involving large groups of potential claimants who-due to the inconsequential amount of individual damages - are not interested in pursuing their claims. ${ }^{117}$ The preferable approach

\footnotetext{
${ }^{106}$ Borwiek \& Klinger, supra note 54 , at 4 .

${ }^{107}$ Alexandra D. Lahav, Are Class Actions Unconstitutional?, 109 Mich. L. Rev. 993, 997 (2011).

${ }^{108}$ Philipp Behrend \& Donata Freiin von Enzberg, Auf dem Weg zur Class Action in Europa?, in RECHT DER INTERNATIONALEN WIRTSCHAFT 253, 254 (2014).

${ }^{109}$ Domej, supra note 58 , at 452 .

${ }^{110}$ ŞAHIN, supra note 15 , at 112 .

${ }^{111}$ Mick Baart, Implications of Commission Recommendation 2013/39 on Common Principles for Collective Redress, Nederlands Internationaal Privaatrecht 489, 496 (2013); J.G. Delatre, Beyond the White Paper: Rethinking the Commission's Proposal on Private Antitrust Litigation, 8 Competition L. Rev. 29, 30, 46 (2011).

${ }^{112}$ Baart, supra note 111 , at 496 . See also ŞAHIN, supra note 15 , at 114.

${ }^{113}$ ReDish 2, supra note 85 , at 136 .

${ }^{114} I d$.

${ }^{115} \mathrm{Id}$. at 159 .

${ }^{116} I d$. at 174 .

${ }^{117}$ Aneta Wiewiórowska-Domagalska, Collective Redress in the Member States of the European UniON 208 (2018).
} 
consists of implementing the opt-out principle, and simultaneously meeting the aforementioned objections in the context of the level of participation.

\section{Level of Participation}

In the German model declaratory lawsuit, according to sections 607 (3) sentence 1 and 609 (3) of the German Code of Civil Procedure, applicants only possess passive information possibilitiessuch as public announcement of, inter alia, references and interim decisions in the register of claims. ${ }^{118}$ It is therefore undisputed that the applicant does not have a sufficient right to a fair hearing, as guaranteed by Article 103 (1) of the German Constitution, and most other legal systems. ${ }^{119}$ According to the justification given by the federal government, the voluntary nature of the application justifies the hearing deficiency - the consumer's legal protection possibilities are improved because they are free to bring an individual action in full procedural status at their own expense. ${ }^{120}$ However, this argumentation confuses separate issues. The legal protection is extended only as it relates to access to the court, whereas Article 103 (1) of the German Constitution deals with a kind of exchange - the cost risk with the sovereignty to organize individual proceedings against freedom of cost exchanged with the cost risk related to the German model declaratory lawsuit being determined by third parties. ${ }^{121}$ Therefore, the binding effect pursuant to Section 613 (1) of the German Code of Civil Procedure, as well as the passive role pursuant to Section 606 of the German Code of Civil Procedure, are deemed unconstitutional insofar as this provision excludes consumers from the right to sue. ${ }^{122}$ An appropriate solution to this problem would be an adequate management process that works towards a sufficient basis for evaluation before the first day of the oral hearing. ${ }^{123}$ Such a provision could also be implemented in an American-style class action.

\section{Scope of Participation}

Mass torts and small claims may concern different groups of persons, such as entrepreneurs, employees, and consumers. While some systems of collective redress, like the American class action, or the Dutch group settlement, are open to all persons, others are restricted to only one group. For example, the French action de groupe according to the Code de la consummation, the German model declaratory lawsuit, and the European representative action, apply only to consumer matters. The Polish civil procedure contains both a group action procedure of judicial nature - albeit not generally permitted in civil cases - and a representative injunctive procedure of an administrative nature in consumer cases. ${ }^{124}$

The restriction to consumer matters is unconvincing. ${ }^{125}$ Although consumers are particularly affected by small claims and mass torts, entrepreneurial competitors and buyers, especially small and medium-sized enterprises, are affected as well. ${ }^{126}$ Rail accidents affect leisure travelers as well as business travelers. ${ }^{127}$ Moreover, diesel cars are more frequently used for commercial purposes

\footnotetext{
${ }^{118}$ Zivilprozessordnung [ZPO] [CODE OF Civil Procedure], \$\$ 607(3), 609(3)

${ }^{119}$ Koch, supra note 21 , at 1415 ; Röthemeyer, supra note 55 , at 7.

${ }^{120}$ Deutscher Bundestag: Drucksachen [BT] 19/2439 (Ger.).

${ }^{121}$ Röthemeyer, supra note 55 , at 7.

${ }^{122} I d$. at 9 .

${ }^{123} \mathrm{Id}$. at 10

${ }^{124}$ Magdalena Tulibacka, Focus on Collective Redress, British Institute of InTERnAtional AND COMPARATIVE LAW, https://www.collectiveredress.org/collective-redress/reports/poland/overview; WIEWIÓROWSKA-DOMAGALSKA, supra note 117 , at 205.

${ }^{125}$ Axel Halfmeier, Musterfeststellungsklage: Nicht Gut, Aber Besser Als Nichts, in ZEITSCHRIFT FÜR RECHTSPOLITIK 201, 202 (2017); Koch, supra note 21, at 1415.

${ }^{126}$ Meller-Hannich, supra note 18 , at 35 ; Scholl, supra note 31 , at 338.

${ }^{127}$ Halfmeier, supra note 125, at 202.
} 
than for personal use. ${ }^{128}$ In addition, the purpose of the law is to reduce incentives for efficient breaches of law, and as such, undue competitive advantages can only be prevented comprehensively if all existing claims for damages can be enforced in court. The possibility for entrepreneurs to suspend their individual trial in order to await the outcome of the model declaratory lawsuit, as Section 148 (2) of the German Code of Civil Procedure provides, is not an adequate substitute. ${ }^{129}$ Therefore, it would be preferable if entrepreneurs and business associations can take part in the lawsuit. ${ }^{130}$ Furthermore, including employees and trade unions as well is worth consideration because it would enable them to sue for discrimination-related claims. ${ }^{131}$

Finally, the purpose of levelling the playing field also requires the inclusion of at least small entrepreneurs. Small businesses often more closely resemble consumers than do large businesses. ${ }^{132}$ Accordingly, in civil proceedings against large businesses, they experience the same inferior position as consumers. This inferior position is brought about by the lack of resources. Most small businesses are financially entwined with their founders. To finance the business, founders often mortgage their homes, draw down their savings, and use their personal credit cards. ${ }^{133}$ In addition, small businesses are less able to amortize legal and other costs over large volumes of transactions, lacking economies of scale, and therefore are not able to operate with the same level of sophistication as their larger counterparts. ${ }^{134}$ Moreover, small entrepreneurs typically have less information than larger businesses-and fewer transactions and trials generally mean less feedback. It is unlikely that small entrepreneurs will hire sophisticated legal counsel when they seek assistance. Along with being disadvantaged by product and market information, these entities are disadvantaged due to only being able to afford inferior legal advice. $^{135}$

\section{Possible Outcomes and Binding Effect}

The possible outcomes of collective redress regimes vary in several ways. There are two types of judgments_-judgements granting performance and declaratory judgements. The German model declaratory lawsuit seeks a declaratory judgement. This solution is supported by the fact that conditions for liability have to be assessed in each individual case. ${ }^{136}$ Nevertheless, the ability to only provide a declaratory judgement is considered to be a major shortcoming in the German approach, and does not set a good example. ${ }^{137}$ The goal of damaged persons is usually to obtain enforceable title in order to get compensation. The mere determination of facts and legal issues does not oblige the defendant to act. The declaratory judgement has no further legal consequences, meaning that the damaged party will not be compensated, nor will the unlawful business practice will not be prohibited in the future. If the company does not voluntarily pay compensation, the damaged party has to then file an individual lawsuit. The defendant companies

\footnotetext{
${ }^{128}$ Scholl, supra note 31 , at $338-39$.

${ }^{129}$ Koch, supra note 21 , at 1415.

${ }^{130}$ Meller-Hannich, supra note 18 , at 7; Scholl, supra note 31 , at 339.

${ }^{131}$ Scholl, supra note 31 , at 339.

${ }^{132}$ Larry Garvin, Small Business and the False Dichotomies of Contract Law, 40 WAKE FOREST L. REV. 295, 308 (2005); Amelia Fletcher, Antony Karatzas \& Antje Kreutzmann-Gallasch, Small Businesses As Consumers: Are They Sufficiently Well Protected? A Report for The Federation of Small Businesses, ESRC CENTRE FOR COMPETITION POLICY (Jan. 2014), https://slidelegend.com/research-bulletin-centre-for-competition-policy_59d74b551723dd5258a6815a.html; Aviva Freilich \& Eileen Webb, Small Business_Forgotten and in Need of Protection From Unfairness?, 37 UnIV. W. AUSTL. L. REV., 134,155 (2013).

${ }^{133}$ Justin G. Longenecker, Carlos W. Moore \& J. William Petty, Small Business Management: An ENTREPRENEURIAL EMPHASIS, 239 (12th ed. 2002); Garvin, supra note 132, at 306.

${ }^{134}$ Garvin, supra note 132 , at 306.

${ }^{135} I d$. at 313; Freilich \& Webb, supra note 132 , at 139.

${ }^{136}$ Scholl, supra note 31 , at 337.

${ }^{137}$ Halfmeier, supra note 125 , at 203; Kranz, supra note 25, at 1102; Koch, supra note 21, at 1414.
} 
are unwilling to settle the model declaratory lawsuit. ${ }^{138}$ With regard to small claims, the German approach will hardly reduce the rational disinterest of consumers. ${ }^{139}$ In the case of mass torts, it is even more important to provide a regulation which permits enforcement, like the American class action does. ${ }^{140}$ Rule 23(b)(3) FRCP meets the differing circumstances by requiring that courts find questions of law or fact common to class members predominate over other questions affecting only individual class members. ${ }^{141}$ Class actions fail under this requirement if the damages incurred diverge too much. ${ }^{142}$

A further distinction is made between injunctive and compensatory redress. Whereas all European Union Member States comply with injunctive collective redress, they approach compensation differently. ${ }^{143}$ The directive enables qualified entities to seek collective injunctive relief and collective compensatory redress within a single device. ${ }^{144}$ Such a model is beneficial, as the individual damaged party is primarily interested in compensation, and the general public is interested in the prohibition of the defendant's practice.

Finally, it is important that the binding effect of the judgement affects all parties alike. A decision in favor of the company should be as enforceable as a decision in favor of the consumers. Anything else would be incompatible with the principle of equality of arms. The current directive proposal does not sufficiently take this into account, as the German Federal Council rightly observed. ${ }^{145}$

\section{Avoidance of Abuse Actions}

If the collective redress adheres to the model of the American class action, it has to take account for the risk of abuse, which is debated in the United States. Justice Ruth Bader Ginsburg recognized that "[a] court's decision to certify a class ... places pressure on the defendant to settle even unmeritorious claims." 46 Then Chief-Judge Richard Posner added that certification of a class action, even one lacking in merit, forced defendants "to stake their companies on the outcome of a single jury trial, or be forced by fear of the risk of bankruptcy to settle even if they have no legal liability." 147 According to Judge Diane Wood, certification "is, in effect, the whole case."148 It receives confirmation by empirical evidence. A study conducted by the Federal Judicial Center concludes that "[e]very case in which a motion to certify was granted, unconditionally or for settlement purposes, resulted in a class settlement." ${ }^{49}$ The merits of the claims do not seem to matter. ${ }^{150}$ Handler even speaks of it as "legalized blackmail."151

\footnotetext{
${ }^{138}$ Halfmeier, supra note 125, at 203; Heese, supra note 18, at 436; Stadler 2, supra note 102, at 799; Koch, supra note 21, at 1414.

${ }^{139}$ Meller-Hannich, supra note 18, at 55; Susanne Augenhofer, Die Rechtsform des Verbraucherrechts durch den "New Deal" - ein Schritt zu einer effektiven Rechtsdurchsetzung?, in EUROPÄISCHE ZEITSCHRIFT FÜr WIRTSCHAFTSRECHT 5, 13 (2019).

${ }^{140} \mathrm{Kranz}$, supra note 25, at 1102; Stadler 2, supra note 102, at 800; Koch, supra note 21, at 1415.

${ }^{141}$ FeD. R. CIV. P. 23(b)(3).

${ }^{142}$ See Wal-Mart Stores, Inc., 564 U.S. at 338.

${ }^{143}$ Amaro et al., supra note 12 , at 71.

${ }^{144}$ Proposal for a Directive of the European Parliament and of the Council on Representative Actions for the Protection of the Collective Interests of Consumers, and Repealing Directive 2009/22/EC, at 3, COM (2018) 184 final (Apr. 11, 2018).

${ }^{145}$ Opinion of the German Federal Council of July 6, 2018, BUNDESRAT DRUCKSACHEN [BR] 155/18 (Ger.).

${ }^{146}$ Shady Grove Orthopedic Assocs. v. Allstate Ins. Co., 559 U.S. 393, 445 (2010) (Ginsburg, J., dissenting).

${ }^{147}$ In re Rhone-Poulenc Rorer Inc., 51 F.3d 1293, 1299 (7th Cir. 1995).

${ }^{148}$ Diane Wood, Remarks at the FTC Workshop: Protecting Consumer Interests in Class Actions, 18 GEO. J. LEGAL ETHICS 1197, 1213 (2005).

${ }^{149}$ Emery G. Lee III \& Thomas E. Willging, The Impact of the Class Action Fairness Act on the Federal Courts: Preliminary Findings from Phase Two's Pre-CAFA Sample of Diversity Class Actions, 156 U. PA. L. ReV. 1723 (2008).

${ }^{150}$ See Allan Ides, Christopher N. May \& Simona Grossi, Civil Procedure: Cases and Problems (5th ed. 2016); but see Hay \& Rosenberg, supra note 86 , at 1378.

${ }^{151}$ Milton Handler, The Shift from Substantive to Procedural Innovations in Antitrust Suits, 71 ColuM. L. REV. 1, 9 (1971); see also GEIGER, supra note 18, at 100; Heese, supra note 18, at 432; Scholl, supra note 31, at 329.
} 
The right question is how much pressure to settle can legitimately be generated by a procedural instrument and its framework conditions. ${ }^{152}$ Requiring losing parties to bear the costs has been an effective precaution against abusive actions. ${ }^{153}$ The loser-pays principle applies in most jurisdictions; for example, in Austria, Estonia, Italy, the Netherlands, Poland, and the United Kingdom. Under Polish Law, according to Article 98 and 108 of the Polish Civil Procedure Code, the loserpays principle is barred by a tariff for lawyers' fees. ${ }^{154}$ The judge also has discretion when it comes to awarding a percentage - or even no costs - to the winner if the loser's circumstances call for it, or if the winner behaved unreasonably during the proceedings. ${ }^{155}$ Accordingly, while the group members must consider the risks of having to pay defendant's costs, these costs are not necessarily exorbitant. ${ }^{156}$ Most authors agree that the loser-pays principle works as a deterrent, albeit there is an absence of empirical evidence as to its efficacy as a deterrent against unmeritorious claims. ${ }^{157}$ Some authors find the loser-pays principle to be problematic in a pure opt-out system, as all members - including those who remained inactive-would be liable for a counterparty's expenses if they lose the case, whereas in an opt-in system, only those opting in are responsible for their share of the counterparty's expenses. ${ }^{158}$ This problem can be solved by including an explanation of the cost risks when notifying class members.

With regard to the plausibility check, the United States judiciary has been stricter in recent years. ${ }^{159}$ Redish suggests the judiciary go even further by explicitly stipulating a requirement that there be a significant likelihood of meaningful relief for the bulk of the absent class members should the class action prove successful, either through verdict or settlement. ${ }^{160}$ As an alternative method for deterring faux class action claims by economically driven attorneys, Redish suggests a modification to the mode of attorney compensation in order to internalize the need for actual client compensation. Currently, class attorneys' compensation is effectively determined as a percentage of the class-wide award or settlement as a whole. ${ }^{161}$ Therefore, compensation is neither determined by the number of claimants, nor the total amount of the award paid out. ${ }^{162}$ According to Redish, attorney compensation should come in the form of coupons providing discounts of some sort for purchase of defendants' products or services. ${ }^{163}$ "[W]hen the litigation dust settles, even in cases in which the plaintiff class prevails (either by means of judgment or settlement), often the overwhelming majority of class members never receive anything approaching meaningful compensation for the defendants' violation of their substantive rights. Instead, they are frequently 'awarded' the opportunity to receive some form of discount coupon for purchase of a product or service already provided by the defendant in the normal course of business." 164

\section{E. Summary and Concluding Assessment}

Collective redress is necessary for several reasons. In particular, it serves the enforcement of the substantive law and the leveling of the playing field between large companies and individual persons. Collective redress can be implemented in different ways. The central parameters of collective

\footnotetext{
${ }^{152}$ Stadler 1, supra note 52, at 636.

153 COFFEe, JR., supra note 97, at 221; Stadler 1, supra note 52, at 637.

${ }^{154}$ WIEWIÓROWSKA-DOMAGALSKA, supra note 117, at 213.

${ }^{155} \mathrm{Id}$.

${ }^{156} \mathrm{Id}$. at 214 .

${ }^{157}$ Amaro et al., supra note 12 , at 260.

${ }^{158} \mathrm{Id}$. at 121 .

${ }^{159}$ See Bell Atlantic Corp. v. Twombly, 550 U.S. 544 (2007).

${ }^{160}$ Redish 2, supra note 85, at 176 .

${ }^{161} I d$.

${ }^{162}$ Ferdinand S. Tinio, Annotation, Attorneys' Fees in Class Actions, 38 A.L.R. Fed. 3d 1384, $\$ 3$ (1971 \& Supp. 2014)

${ }^{163}$ Redish 1, supra note 84 , at 471 .

${ }^{164}$ Redish, Class Actions and the Democratic Difficulty: Rethinking the Intersection of Private Litigation and Public Goals, in U. CHI. LEgAL Forum, at 71, 78 (2003) [hereinafter Redish 3].
} 
redress should be in line with the American class action. As the opt-out principle is preferable in group action, the scope of participation should not be limited to consumers, and the judgement should provide an enforceable title.

There are no compelling reasons not to adopt a class action. In Europe, the American class action is often considered to have an exaggerated impact. ${ }^{165}$ The significant objections can be overcome by selective adjustments, such as a stricter examination of the merits of the case in order to prevent abusive actions. Furthermore, a strict loser-pays rule should be established. ${ }^{166}$ In an opt-out system, class members must be informed of the cost risk. It is true that there are weighty objections raised against the constitutionality of the American regulation. However, they do not affect other jurisdictions-but even then, can be prevented through the design of the regulation. It is also argued that American class actions violate the Rulings Enabling Act and separation of powers principles, because Congress delegated to the Supreme Court the power to create rules of procedure for the federal courts. ${ }^{167}$ Redish notes that this delegation of power does not permit the Court to create rules that transform individual causes of action into "monster litigation."168 This transformation violates separation-of-power principles, and the Rules Enabling Act, because it is achieved through the Supreme Court's rulemaking power rather than by congressional action. ${ }^{169}$ By aggregating claims where the class members are truly absent, the class action would fundamentally transform the underlying right into something else. ${ }^{170}$ According to Redish, that is not what the legislature specifically intended. Often, it is a lawsuit run by lawyers offering no meaningful compensation to individual litigants. Therefore, the procedural rule would impermissibly circumvent legislative intent. ${ }^{171}$ However, this democratic deficit can easily be avoided by proper participation by the legislator.

Furthermore, class actions allegedly violate individual rights by erasing an individual's cause of action in favor of the collective. As a due process matter, rights belong to individuals and cannot be taken away by enacting a procedural rule, unless individuals willingly choose to participate in that process. ${ }^{172}$ Redish argues that litigants have a right to freedom of association or, rather, freedom to be free from association with a class. ${ }^{173}$ For this reason, both mandatory and opt-out class actions would violate due process. Therefore, damages class actions should only be opt-in. ${ }^{174}$ Consequently, claimants who fail to act will not be part of the class action, and will not be precluded from subsequently bringing a competing lawsuit. ${ }^{175}$ This objection underscores a vital problem of the opt-out principle. However, this issue can be rectified by providing appropriate notification to parties. The relevant arrangements in the Member States-meaning the ones who are adopting a group action-are not considered unconstitutional. The possibility to opt-out ensures the right to be free from association with a class. Finally, Redish considers settlement class actions - meaning that lawyers file both the class action complaint and a proposal of settlement at once-unconstitutional because they allegedly violate Article III's case-or-controversy requirement. ${ }^{176}$ This problem concerns the peculiarities of the American legal system, as European jurisdictions do not subscribe to the case-or-controversy requirement.

\footnotetext{
${ }^{165}$ Stadler 1, supra note 52, at 654.

${ }^{166} \mathrm{Id}$.

${ }^{167} 28$ U.S.C. $\$ \$ 2071-72(2006)$.

${ }^{168}$ Redish 3, supra note 164 , at 78.

${ }^{169}$ REDISH 2, supra note 85 , at 30 ; see also Redish 3 , supra note 164 , at 82 .

${ }^{170}$ REDISH 2, supra note 85 , at 14 .

${ }^{171}$ REDISH 2, supra note 85 , at 14 .

${ }^{172} \mathrm{Id}$. at 136 .

${ }^{173} \mathrm{Id}$. at 159 .

${ }^{174} \mathrm{Id}$. at 174 .

${ }^{175}$ Lahav, supra note 107 , at 997.

${ }^{176}$ ReDish 2, supra note 85, at 176; Martin H. Redish \& Adrianna D. Kastanek, Settlement Class Actions, the Case-orControversy Requirement, and the Nature of the Adjudicatory Process, 73 U. CHI. L. REV. 545 (2006).
} 
As it is unlikely that either the European Union or every individual Member State will adopt a regulation pursuant to the above-mentioned standards, this Article concludes with remarks on the directive on collective redress, as it is the most probable future scenario. The directive has some advantages. The single-stage approach is preferable to the two-stage approach seen in the German model declaratory lawsuit, as consumers do not have to file an individual lawsuit if the company fails to pay, even after the company loses in court. ${ }^{177}$ Consumers should also be informed of final decisions providing for injunction measures, redress measures, or approved settlements (Recital 31a of the directive on representative actions). ${ }^{178}$ The law can only be effective if participants in the legal system are aware of their rights and duties. According to Recital 31a, it should be for Member States to decide who should be responsible for disseminating the information. ${ }^{179}$ Otherwise, it would overburden the companies if they have to disseminate such information. ${ }^{180}$ However, that should not pose an issue, as companies enjoy favorable financial situations. ${ }^{181}$ Recital 31a correctly stresses the deterring effect: "The reputational risks associated with spreading information about the infringement are also important for deterring traders infringing consumer rights." Overall, the directive is a step in the right direction, but its implementation can be improved. ${ }^{182}$

At various points, the directive remains too vague. According to Article 12 (1) of the directive on representative actions, Member States shall ensure that representative actions for injunction measures are treated "with due expediency." 183 Indeed, there is a need to ensure faster processing, as seen through the experiences with national forums of collective redress. ${ }^{184}$ In light of this problem, a specific requirement would be desirable. ${ }^{185}$ Another point that attracts criticism is the fact that the directive does not require a minimum number of affected consumers. ${ }^{186}$ According to Article 3 (3), "collective interests of consumers" refers to the general interests of consumers and, in particular, for the purpose of redress measures, the interests of a "group of consumers." 187 The original proposal was even more vague, as it spoke of a "number of consumers." Overall, the final agreement still leaves Member States too much room for maneuvering in implementation. ${ }^{188}$ This could mean that individual Member States reduce the option for qualified entities to file legal action to the point of being ineffective, and allowing for amendments only after a lengthy proceeding before the European Court of Justice. ${ }^{189}$ In order to avoid abusive actions, the introduction of the loser-pays principle should be implemented, as Recital 13c of the directive suggests, after the former version left this matter entirely to the Member States. The same applies with regard to the nature of participation-the reports by Member States unanimously agree that the choice between the opt-in principle and the preferable opt-out principle should not be left to the sole discretion of European Member States, as Recital 15b indicates. ${ }^{190}$

The restriction of the scope to consumers might be due to the limited legislative power of the European Union. According to Article 4 (1) of the Treaty on the Functioning of the European

\footnotetext{
${ }^{177}$ Augenhofer, supra note 139 , at 13.

${ }^{178}$ Council Directive 9223/20, supra note 13, Recital 31a.

${ }^{179} I d$.

${ }^{180}$ Deutscher BundesRat: DrucKSACHen [BR] 155/18 (Ger.).

${ }^{181}$ Augenhofer, supra note 139 , at 12.

${ }^{182}$ Id. at 13; Halfmeier \& Rott, supra note 99, at 250; Tobias Lühmann, Der Vorschlag einer europäischen Verbandsklage. Ein weiteres Instrument des kollektiven Rechtsschutzes, in NeUE JURISTISCHE WOCHENSCHRIFT 570, 575 (2019).

${ }^{183}$ Council Directive 9223/20, supra note 13, Article 12(1).

${ }^{184}$ Susanne Augenhofer, Gutachten im Auftrag ddes vzbv: Deutsche und europäische Initiativen zur Durchsetzung des Verbraucherrechts, 2018, VERBRAUCHERZENTRALE BUNDESVERBAND E.V. (May 9, 2018), https://www.vzbv.de/sites/default/ files/downloads/2018/05/08/19-05-08_vzbv_gutachten_augenhofer.pdf.

${ }^{185}$ Augenhofer, supra note 139 , at 13.

${ }^{186}$ Deutscher BundesRat: DRUCKSACHEN [BR] 155/18 (Ger.).

${ }^{187}$ Council Directive 9223/20, supra note 13, Article 3(3).

${ }^{188}$ Augenhofer, supra note 139, at 13; Halfmeier \& Rott, supra note 99, at 250.

${ }^{189}$ Halfmeier \& Rott, supra note 99, at 250.

${ }^{190}$ Amaro et al., supra note 12 , at 86.
} 
Union (TFEU), the European Union has full legislative power in the field of consumer protection. ${ }^{191}$ In contrast, the legislative power in the field of civil procedure is limited to the access to justice, in particular, through the principle of mutual recognition of judicial and extrajudicial decisions in civil matters (Article 67 (4) TFEU) and to judicial cooperation in civil matters having cross-border implications (Article $81 \mathrm{TF}-\mathrm{EU}) .{ }^{192}$ Accordingly, the inclusion of small entrepreneurs can only be implemented by the Member States.

\footnotetext{
${ }^{191}$ Consolidated Version of the Treaty on the Functioning of the European Union, art. art. 4(1), May 9, 2008, 2008 O.J. (C 115) 47.

${ }^{192} I d$. at arts. $67(4), 81$.

Cite this article: Stöhr A (2020). The Implementation of Collective Redress - A Comparative Approach. German Law Journal 21, 1606-1624. https://doi.org/10.1017/glj.2020.95
} 